\title{
慢性腎不全患者での血漿中硫化水素濃度の測定
}

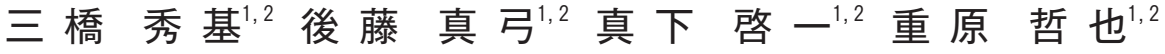 \\ 矢野 新太郎 ${ }^{1,2}$ \\ 上毛大橋クリニック ${ }^{1}$ 群馬腎リウマチ研究所 ${ }^{2}$
}

キーワード : 硫化水素, 透析, 腎不全, 血漿中濃度

〈要旨〉

危険な有毒ガスとして知られる硫化水素がヒト体内でもシステインから cystathionine $\beta$-synthase (CBS) や cystathionine rlyase（CSE）により産生されることが知られている. この物質は神経伝達物質や血管作動性物質と しての働きが認められ，第 3 のガス状メディエーターとして認識されつつある. しかし，血液中硫化水素の濃度測 定は低濃度であり干渉する物質の存在のため難しく臨床的研究は数少ない. 一方, 腎不全では含硫アミノ酸代謝異 常がおこりシステインや亜硫酸などの硫黄化合物が血中に上昇することが知られている. われわれは透析患者にお いて硫化水素代謝異常の可能性を推測し, 高速液体クロマトグラフィー (high performance liquid chromatography : HPLC) を用いた Savage 法にて日本人透析患者の血中硫化水素濃度を測定した. 液中に添加された硫化水素 を経時的に計測してみると, 純水中や血漿中の硫化水素は経時的に減少した. 血液中の硫化水素はそれらよりさら に急速に失われる傾向があることから, 血中の硫化水素濃度測定には採血後に迅速な処理が必要であることが明ら かとなった. 血漿中の硫化水素濃度は透析患者においては正常者血中濃度よりも有意に上昇していた. さらに, 血 漿中硫化水素濃度は慢性糸球体腎炎群に比較して糖尿病群で有意に低かった. そして, 単回の透析治療により透析 前に上昇している血中硫化水素濃度は正常血清レベル以下まで低下した. また, 透析治療中の透析排液中に硫化水 素が検出された. これらのことから透析患者では硫化水素産生能進または消去能低下のため硫化水素が恒常的に 血液中に増加しており透析により除去されることがわかった.

\section{Plasma concentrations of hydrogen sulfide in patients with hemodialysis}

Hideki Mitsuhashi ${ }^{1,2}$, Mayumi Gotoh ${ }^{1,2}$, Keiichi Mashimo $^{1,2}$, Tetsuya Shigehara ${ }^{1,2}$ and Shintaro Yano ${ }^{1,2}$ Jomo Ohashi Clinic ${ }^{1}$ and Gunma Research Center of Nephrology and Rheumatism ${ }^{2}$

Key words : hydrogen sulfide, hemodialysis, renal failure, plasma concentration

〈Abstract〉

In Japanese patients treated with hemodialysis, blood concentrations of sulfur-containing substances such as cysteine or sulfite are increased. Recently, hydrogen sulfide has been recognized as the third gaseous mediator that functions in tissues such as brain and vessel. It is produced from cysteine by cystathione $\beta$-synthase (CBS) or cystathionine rlyase (CSE) in the mammalian body. However, it is difficult to measure the concentration of hydrogen sulfide in blood, because of several interfering substances that impede analysis. In this study, we measured blood concentrations of hydrogen sulfide in hemodialysis patients by Savage's method using high performance liquid chromatography (HPLC). Concentrations of hydrogen sulfide were gradually decreased in water and plasma. Furthermore, there was a tendency for the concentrations of hydrogen sulfide to decrease much faster in blood. In patients treated with hemodialysis, mean plasma hydrogen sulfide was significantly higher than that in healthy controls. Mean plasma hydrogen sulfide in patients with diabetes mellitus was significantly lower than that in patients with glomerulonephritis. Concentrations of hydrogen sulfide were significantly decreased during hemodialysis treatment. Hydrogen sulfide was detected in liquid from the dialyzer at the initial step of each therapy session. Therefore, increase in hydrogen sulfide in blood caused by renal failure is removed by hemodialysis.

三橋 秀基 上毛大橋クリニック％ 371-0046 群馬県前橋市川原町 531-4

Hideki Mitsuhashi Tel : 027-237-2800 Fax : 027-210-3611

〔受付日：2010 年 9 月 16 日, 受理日：2011 年 1 月 19 日〕 


\section{緒言}

原始の地球大気において中心的ガスであった硫化水 素は現在も火山口などで高濃度に存在し，青酸ガスと 同レベルの有毒ガスとして知られる. 多くの生物にと り吸気中高濃度の硫化水素は動物体内に取り达まれた あとミトコンドリアのチトクロームオキシダーゼを阻 害し細胞呼吸を障害して一瞬にして死に到らしめ $ろ^{1)}$. 一方, 近年の研究でこの物質は哺乳類体内にお いて産生されることが認識されている。たとえば，口 腔内や腸管内では嫌気性細菌により硫化水素は産生さ れ，歯槽膿漏や消化管機能への影響がいわれている2). また, 体内臓器から生成される硫化水素が一酸化窒素 や一酸化炭素に続くガス状メディエーターとして認識 されつつあり, 神経細胞の機能調節作用や血圧調節作 用がいわれている゙).

以前から硫黄化合物の代謝異常が腎不全患者で起こ り，血中の硫黄代謝物が上昇することが知られる ${ }^{4)}$. たとえばホモシステインは血液中の濃度が上昇し血栓 疾患に関係するといわれ，その臓器障害性作用が問題 になっている5). また, われわれはガス状の硫黄酸化 物である亜硫酸が腎不全患者において血中で上昇して いることを明らかにしだ). cystathionine $\beta$-synthas (CBS) や cystachionine rlyase (CSE) により硫化水素 に変換されるシステインも血中で透析患者では上昇し ている ${ }^{7)}$.これらのことや硫化水素は硫酸基に変換さ

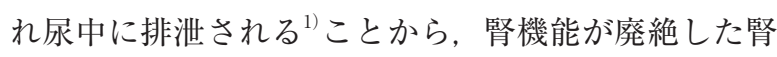
不全患者において血中硫化水素濃度も異常を示すこと が予測される。

現在までのところ硫化水素に関する基礎的研究は進 んできているが, 臨床的デー夕は少ない. 硫化水素濃 度は温泉などで測定されるが, そのためには現場で迅 速な処理法が必要である ${ }^{8)}$. 温泉中の硫化水素濃度な どは簡便な比色定量法で行われるが, 血液中ではさら に低濃度であり感度や特異性の問題があるためこう いった方法では臨床的検討は難しい，そのためより感 度と特異性の面で有利な高速液体クロマトグラフィー (high performance liquid chromatography : HPLC) を利用した Savage 法 $^{9.10)}$ で透析患者の血中濃度につ き臨床的検討を行った.

\section{I . 対象と方法}

\section{1. 対 象}

既往歴がなく内服を行っていない健康成人 $(n=12)$
の健康診断時採血と当院に通う透析患者 $(n=20)$ の 定期採血の一部にて計測した。採血は穿刺直後と回収 操作開始直前に行った. 血液透析方法は, 一回 4 5 時間, 週 3 回, 血流量は 150〜 $200 \mathrm{~mL} / \mathrm{min}$, 透析液 (全 員無酢酸透析液) 流量 $500 \mathrm{~mL} / \mathrm{min}$ であった。透析患 者は採血前 2 週間以内に胸部 X 線写真や HANP 值に より適正なドライウェイトにコントロールされている と判断した。 また， $\mathrm{KT} / \mathrm{V}$ は毎月測定され $1.4 〜 1.6$ を得られていた。患者は肝炎などの感染症はなく, 貧 血もエリスロポエチンで治療を受けていた．多くの患 者でカルシウムチャンネル阻害剤やアンジオテンシン II 受容体阻害剂などの降圧剤を使用していた。さら に, 測定全例で透析中血圧は安定しておりメチル硫酸 アメジニウム等は必要としていなかった。 そして, 糖 尿病患者ではインシュリンと食事療法で加療してい た. 平均年齢は健康成人 $48.6 \pm 14.6$ 歳, 透析患者 $54.2 \pm 18.2$ 歳で透析歴は $10.3 \pm 6.3$ 年である. ヘル シンキ宣言に基づき承諾書を得てから検査を行った.

\section{2. 方 法}

島津 HPLC システムを使用した（LC6A，CTO6A， SPD-6AV, C-R6A). 紫外線計測は $670 \mathrm{~nm}$ に設定し, $1.5 \mathrm{~mL} / \mathrm{min}$ 等速流量で Hamilton PRP-1 カラム（Reno, NV, USA ; $250 \mathrm{~mm} \times 4.6 \mathrm{~mm}, 10 \mu \mathrm{m})$ を使用し 測定した。アアン液のストック液は $\mathrm{N}, \mathrm{N}$-dimethylp-phenylenediamine (Sigma, St.Louis, MO, USA) $12 \mathrm{~g}$ を $80 \mathrm{~mL}$ の $9.0 \mathrm{M}$ 硫酸（和光）に溶解して作製. アミン液は $9.0 \mathrm{M}$ 硫酸に 40 倍でストック液を薄め使 用前にその都度作製する。酸化試薬は $50 \mathrm{~g}$ の ferric chloride (Sigma, St. Louis, MO, USA) を $100 \mathrm{~mL} の$ MilliQ 水に溶解作製. スタンダードとしての硫化水素 液は sodium sulfide（NaHS, 和光）を MilliQ 水に溶解 し計測のたびに作製した。液体クロマトグラフィーの 移動相は 35\% acetonitrile (Sigma, St. Louis, MO, USA) $/ 0.5 \%$ 酢酸（和光) $/ 64.5 \%$ Milli-Q 水に p-toluenesulfonic acid（Sigma, St. Louis, MO, USA）を 5 $\mathrm{mM}$ で溶解した。

検体処理は $0.4 \mathrm{~mL}$ の血漿に $8 \mu \mathrm{L}$ の $0.5 \%$ 酢酸亜鉛 （和光）を加え, さらに0.8 mL の MilliQ 水を加えた後 に $0.4 \mathrm{~mL}$ のアミン液を加える. 最後に $16 \mu \mathrm{L}$ の酸化 試薬を加えて室温に 30 分放置してから，3 分間 4,000 $\mathrm{g}$ で遠心する. 上澄みを $0.45 \mu \mathrm{m}$ のフィルター処理し てから分析に使用した。

平均值を記載する際には, 平均土標準偏差で表記し た. 統計処理は pairedおよび unpaired Student's t test などを用いて $\mathrm{p}<0.05$ で有意差ありとした。 ま た, 2 群の相関関係はスピアマンの相関係数を用いた。 


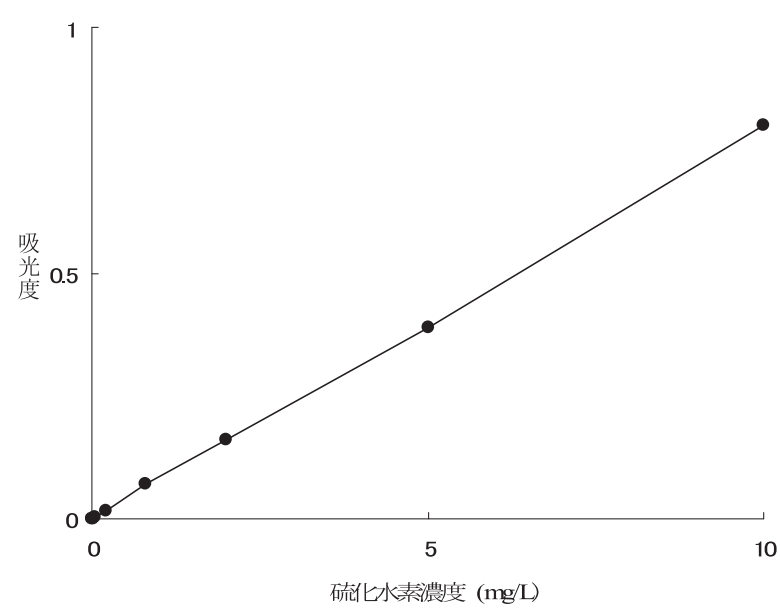

図 1 Correlation between $\mathrm{H}_{2} \mathrm{~S}$ concentrations and UV absorbance

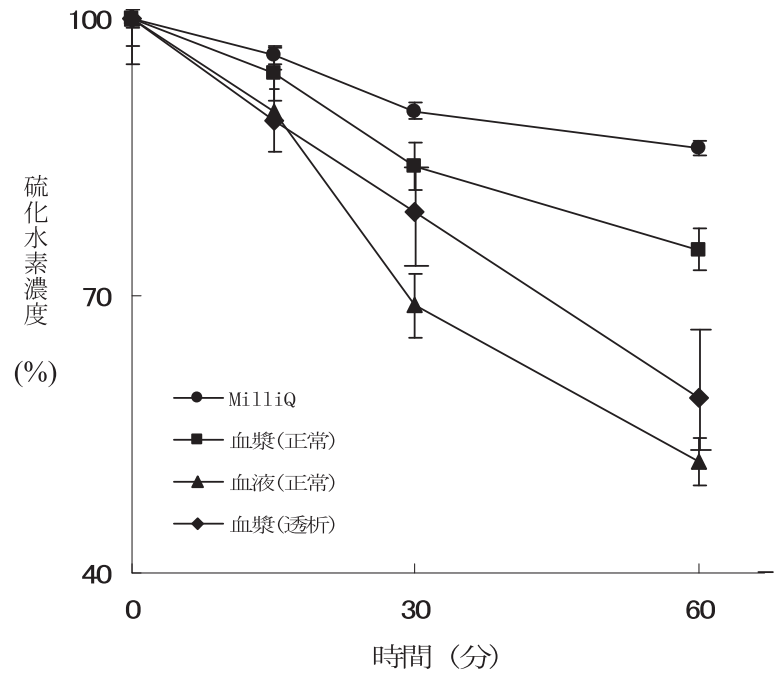

図 2 Plot of disappearance rate of $\mathrm{H}_{2} \mathrm{~S}$ during incubation $(n=3)$

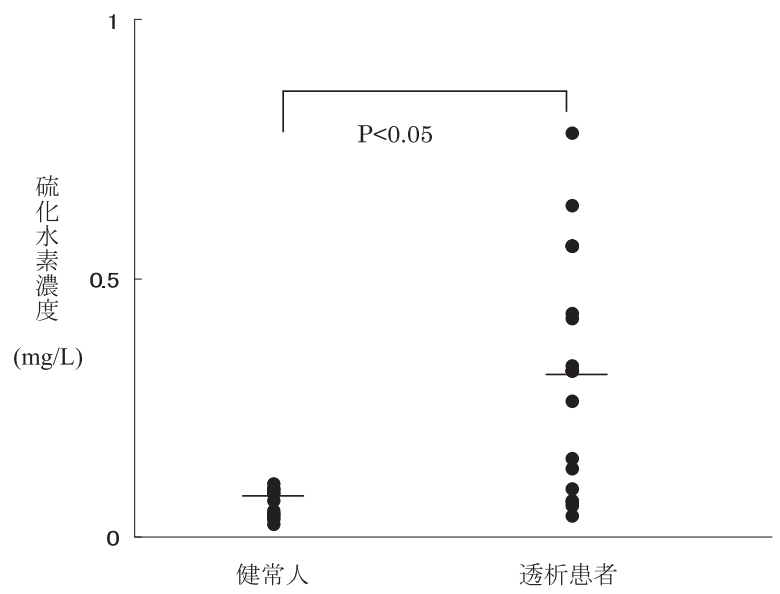

図 3 Comparison of $\mathrm{H}_{2} \mathrm{~S}$ concentrations in plasma of healthy subjects $(n=12)$ and HD patients $(n=20)$

であった，透析患者 $(\mathrm{n}=20)$ の血中濃度は $0.38 \pm$ $0.23 \mathrm{mg} / \mathrm{L}$ であり，有意に健常人よりも高い濃度を示 した（図 3).

\section{5. 臨床データと硫化水素濃度との関係}

年齢, 透析歴や $\mathrm{Hb}, \mathrm{CRP}, \mathrm{BUN}$, アルブミンなどの 基礎データと血漿中硫化水素濃度との相関を検討した が有意な相関関係を示さなかった．性別，透析膜，基 礎疾患につき血漿硫化水素の濃度における有意差を計 算し表 1 に示した。基礎疾患のみ有意差を示し, 糖尿 病患者群で腎炎群に比較してかなり低值を示した。こ の 2 群で濃度が大きく異なることが, 透析患者で硫化 水素濃度の測定範囲が大きくばらついた理由の一つと 考えられる。

\section{6. 透析療法の硫化水素濃度への影響}

透析患者 $(n=9$, 糖尿病 3 人, 腎炎 6 人, 最高 0.78 健常人 $(n=12)$ の血中濃度は $0.087 \pm 0.036 \mathrm{mg} / \mathrm{L}$ 
$\mathrm{mg} / \mathrm{L}$ ，最低 $0.089 \mathrm{mg} / \mathrm{L}$ ）で透析開始時と回収時の硫 化水素の血中濃度を比較した（図 4A)。透析開始時の 濃度 $(0.43 \pm 0.24 \mathrm{mg} / \mathrm{L})$ は透析療法により健常人レ ベルより有意に低いレベル $(0.042 \pm 0.018 \mathrm{mg} / \mathrm{L})$ ま で低下した．透析液と透析開始直後に得られた透析回 路から得た廃液（ $n=9 ）$ の硫化水素濃度を調べた。未 使用透析液では硫化水素は検出できなかったが, 全例 の透析廃液中で硫化水素が検出され平均值は $0.018 \pm$ $0.008 \mathrm{mg} / \mathrm{L}$ であった．透析により血液中より除去さ れることが透析前後採血での血中硫化水素濃度低下の 大きな原因と考えられた。また， 1 週間の間隔をおい て 10 人の透析患者で血槳中硫化水素濃度を比較した が，高い相関関係が得られた（図 4B). 血中硫化水素 は透析によりかなりの割合で除去されるが，数日の間 にほぼ同様のレベルまで上昇することがわかった。

\section{まとめ}

硫化水素は液面から蒸発しやすく, 液表層で酸素に

表 1 Correlation between blood $\mathrm{H}_{2} \mathrm{~S}$ concentrations and other variables

\begin{tabular}{lcc}
\hline & 硫化水素濃度 $(\mathrm{mg} / \mathrm{L})$ & P-value \\
\hline 性別 & & N.S. \\
男性 $(\mathrm{n}=12)$ & $0.36 \pm 0.25$ & \\
女性 $(\mathrm{n}=8)$ & $0.31 \pm 0.19$ & \\
透析膜 & & N.S. \\
FDX $(\mathrm{n}=9)$ & $0.33 \pm 0.18$ & \\
APS $(\mathrm{n}=11)$ & $0.34 \pm 0.18$ & \\
原疾患 & & $\mathrm{p}<0.05$ \\
慢性糸球体腎炎 $(\mathrm{n}=12)$ & $0.47 \pm 0.17$ & \\
糖尿病 $(\mathrm{n}=8)$ & $0.15 \pm 0.10$ & \\
\hline
\end{tabular}

よる酸化によっても失われるといわれる ${ }^{11}$. ここで示 したように硫化水素は水や血漿に溶解している状態で 時間経過とともに比較的急速に濃度が低下していく. さらに, 血液の状態ではより低下速度は速い傾向に あった。これは，血液細胞が存在することによる代謝 消去が急速に起こることが理由として考えられる，過 剩の硫化水素は細胞呼吸を瞬時に破壊するが，ある一 定のレベルまでの硫化水素はミトコンドリアにて急速 に酸化消去される ${ }^{12)}$. ミトコンドリアのない赤血球へ の硫化水素の作用はよく知られていない. しかし, 硫 化水素は細胞膜透過性が高いうえにへモグロビン蛋白 に結合しやすいといわれ，赤血球細胞に吸収された可 能性もある ${ }^{12,13)}$ ．温泉などの硫化水素を測る際に採取 場で液中の硫化水素をその場で迅速に固定する ${ }^{8)}$. 今 回の実験から血液に打いて正確に安定に硫化水素濃度 を測るため迅速な血漿分離後の酢酸亜鉛固定が重要で あると考えられた。 したがって，われわれは一人ずつ 計測を行った，一度に複数人を採血し計測する場合に は先に採血を行われた人が実際よりも濃度が低值を示 してしまう可能性があり注意が必要である.

近年, Perna らも透析患者にて硫化水素濃度を測定 している. 彼らの研究では透析患者に扔いてその血中 濃度は健常人に比較してわずかに低值を示していて, われわれの研究と異なる結果となっている. その理由 は二つ考えることができる。一つは人種差や環境の影 響が考えられる. 表現している単位がこの二つの研究 で異なるが, 透析患者での濃度は両研究で近いレベル にある，以前，同様なガス状物質である亜硫酸濃度を 正常人血液中で測定した．日本人では欧州人の 3 分の 1 程度の亜硫酸濃度であり, 食文化や環境の違いによ

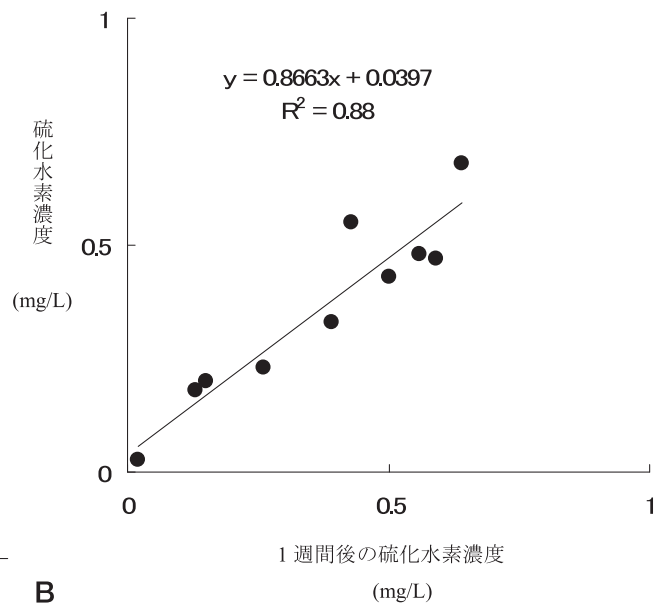

図 4 (A) Changes in $\mathrm{H}_{2} \mathrm{~S}$ concentrations after $\mathrm{HD}$ treatment in 9 patients receiving maintenance $H D$. (B) Correlation of blood hydrogen sulfide concentrations in same HD patients at different treatment days $(n=$ 10). 
ると考えられた ${ }^{6}$. にんにくなどに硫化水素生成の成 分が含まれるが，食事内容が硫化水素産生に影響を与 える可能性がある。イタリア人は野菜や果物を日本人 の三倍も食することが知られる视．つまり，イタリア の正常人に打いて食習慣の違いから日本人より硫化水 素が血中で高值となったが，腎不全患者で透析食とな ることで日本人と同様の血中濃度になる可能性であ る.もう一つはこの二つの研究の測定方法の違いに由 来する可能性である，温泉などと異なり生体試料を簡 便な色素法で測る場合には測定に誤差が出る可能性が あるため, Savage が複雑だが正確な HPLC を使用し た方法を発表している9 。 つまり，色素法では正常人 で硫化水素濃度が高くなるが, 腎不全物質が反応を阻 害して逆に透析患者では硫化水素濃度が低く出てし まった可能性である。臨床的な硫化水素研究を広げる ために,この二つの測定法の比較検討が今後必要であ る.

CBS や CSE などの硫化水素産生酵素は神経組織や 血管など体内に広く同定されていで3)，これらが血液 中の硫化水素の大きな産生源と考えられる.すでに知 られるように透析患者では硫黄関連代謝が障害されシ ステイン, ホモシステインや亜硫酸などが血中に高值 を示す ${ }^{4,5)}$. 今回得られた透析患者での血中濃度の上 昇は硫化水素産生の原料となる物質の上昇に伴い産生 が充進した可能性が考えられる。また，透析患者は便 秘などの消化器異常を伴いやすく, 腸管内発生硫化水 素の消化管からの吸収経路も否定できない，一方で腎 不全での硫化水素消去能の変化も推測できる. 硫化水 素はその毒性から正常では狭い範囲の濃度に厳密にコ ントロールされていて消去メカニズムも存在する．た とえば，吸入された硫化水素は体内に入り速やかにミ トコンドリアのチトクロームオキシダーゼにより酸化 され硫酸基に変化し尿路系から排泄される ${ }^{1)}$. しか し，透析患者に扔いてミトコンドリアの機能異常が存 在していることが知られており ${ }^{15)}$ ，ミトコンドリアに よる消去能低下や腎不全による尿中排泄低下が㧍こり 硫化水素が蓄積される可能性も考えられる。

血漿中硫化水素濃度は糖尿病群で慢性系球体腎炎群 より有意に低值を示した，その原因を今回の研究から 明らかにすることはできないが，いくつかその理由を 過去の知見から推察できる。まず，硫化水素生成の原 料となるシステインの血中濃度の違いによるものであ る. 非糖尿病腎不全患者で血中に増加しているシステ インが糖尿病腎不全患者では低下していることが報告 されている ${ }^{5,16)}$ ，そのために糖尿病腎不全患者では血 管からの硫化水素産生が減少する可能性である. 次
に，糖尿病による腎不全患者で起こる重度の血管障害 によるものである，石灰化に至っているような状態で は血管からの硫化水素産生が減少するが(7)，糖尿病腎 不全患者においては石灰化などの血管障害が非糖尿病 腎不全患者より重度であることが報告されてい $3^{18,19)}$. つまり, 糖尿病腎不全患者で血管に扔ける生 物学的利用能低下が起きているためである。これらの ことを明らかにするために，糖尿病腎不全患者での血 中含硫アミノ酸濃度と硫化水素濃度の相関などの臨床 的検討や糖尿病のモデル動物における血管臟器などで の硫化水素産生能の検討が有用と思われる.

硫化水素は吸入された場合極めて有毒な物質である ため, 環境の点からその空気中濃度と人体に与える濃 度についてはすでによく研究されている1).しかし，

一般に研究されている硫化水素の役割はワンショット での検討が多く, 恒常的な硫化水素の体内での上昇が いかなる働きをするかわかっていない，今のところ， NaHS を単発投与した研究が主であるが, 硫化水素の 哺乳類への有用な役割としては血管弛緩による血圧低 下作用が考えられている ${ }^{20.21)}$. また, 硫化水素は homocysteine による血管障害作用を抑制することも示 されている ${ }^{22}$ が，今回の研究での腎炎患者において血 中の硫化水素濃度はそれらの濃度に近いレベルであっ た. しかし, 糖尿病群では腎炎群より大きく低下して 抢り, 糖尿病患者では硫化水素による血管保護作用能 力が低下している可能性があると考えられる.さら に，透析により血中硫化水素濃度が正常レベル以下ま で低下することがわかった．血中硫化水素が透析中に 低下することは透析患者が透析前の水分容量増加によ る血圧上昇を緩和するためや透析後体液減少による血 圧低下を防ぐ可能性があり人体に望ましい現象と思わ れる. しかし, 今回の実験で透析開始時の血中硫化水 素濃度にかなり個人差があるにもかかわらず全例で透 析中血圧は落ち着いていた，実際に透析による硫化水 素の除去が透析の血圧低下防御にどれだけ寄与するか 決定するには, 透析除水速度, 除水量, 降圧薬の種類 や透析中の細かな血圧変動などや硫化水素の濃度とそ の変化などのさらに他因子を含めたより大規模な解析 で検討する必要がある。また，中枢神経系への硫化水 素の作用も知られるが血圧に影響を与える自律神経系 への作用はまだ不明であり，その検討も今後必要であ る.

硫化水素のようなガス状物質としてすでに一酸化窒 素が知られている ${ }^{19)}$. 作用点は異なるが一酸化窒素も 血管拡張に働き, 透析患者において一酸化窒素の働き は血行動態的に重要であることがすでに知られる 
また，一酸化窒素は CBS に働き硫化水素産生を高め るといわれるが, この二つの物質は蛋白の $\mathrm{SH}$ 基への 結合においては互いに拮抗することが知られてい $る^{24)}$. 一方で, 硫化水素は哺乳類の細胞の増殖に影響 を与えることが知られる。同じく火山ガス成分であり ながら人体内で産生される亜硫酸は, 酵母などの細胞 では硫化水素と相反して細胞機能を調節することが知 られている ${ }^{25)}$. 以前のわれわれの研究で炎症条件下硫 化水素が亜硫酸に酸化代謝される可能性 ${ }^{10)}$ と, 腎不全 患者での亜硫酸血中濃度上昇を示した ${ }^{6)}$ 。亜硫酸は硫 化水素と逆に平滑筋収縮に働き血圧上昇作用の可能性 がいわれている26).これらのことから腎不全での体内 での硫化水素の作用は一酸化窒素や亜硫酸など他のガ ス状の物質との複雑な相互関係の上に成り立つことが 予測される。

\section{文献}

1) Milby $\mathrm{TH}$, Baselt RC : Hydrogen sulfide poisoning : clarification of some controversial issues. Am J Ind Med 35 : 192-195, 1993

2) Florucci S, Distrutti E, Cirino G, Wallace J : The emerging roles of hydrogen sulfide in the gastrointestinal tract and liver. Gastroenterol 131 : 259-271, 2006

3) Abe K, Kimura $H$ : The possible role of hydrogen sulfide as an endogenous neuromodulater. J Neuroscience $16:$ 1066-1071, 1996

4) Kirschbaum B : Effect of hemodialysis on the hypersulfatemia of chronic renal failure. ASAIO J 44 : 314318, 1998

5) Perna AF, Ingrosso D, Satto E, Romano M, Cimmno A, Galletti P, Zappia U, De Santo NG: Metabolic consequences of hyperhomocysteinemia in uremia. Am J Kidney Dis 38 : s85-s90, 2001

6) Kajiyama H, Nojima Y, Mitsuhashi H, Ueki K, Tamura S, Sekihara T, Wakamatsu R, Yano S, Naruse T : Elevated levels of serum sulfite in patients with chronic renal failure. J Am Soc Nephrol 11 : 923-927, 2000 Channel opener

7) Reis PF, daSilva CD, Brunini TM, Moss MB, Siqueira MA, Santos SF, Roberts NB, Ellory JC, Mann GE, Mendes-Ribeiro AC: Plasma amino acid profile and Larginine in red blood cells from malnourished uremic patients. J Ren Nutr 16 : 325-331, 2006

8）深沢嘉延：光線分析法指針と温泉分析. 温泉化学 49 : 65-75, 1998

9) Savage JC, Gould DH : Determination of sulphide in brain tissue and rumen fluid by ion interaction, highperformance luiquid chlomatography. J Chlomatogr $526: 530-545,1990$

10) Mitsuhashi H, Yamashita S, Ikeuchi H, Kuroiwa T,
Kaneko Y, Hiromura K, Ueki K, Nojima Y : Oxidative stress-dependent conversion of hydrogen sulfide to sulfite by activated neutrophils. Shock $24: 529-534$, 2006

11) Pace NR : A molecular view of microbial diversity and the biosphere. Science $276: 734-740,1997$

12) Moore PK, Bhatia M, Moochhala S:Hydrogen Sulfide : from the smell of the past to the mediator of the future? Trends Pharmacol Sci $24: 609-611,2003$

13) Searcy DG, Lee SH : Sulfur reduction by human erythrocytes. J Exp Zool 282 : 310-322, 1998

14) Nutrition and obesity. World health data book 2007/ 2008, p323-324, Euromonitor Intl. London, 2009

15) Granata S, Zaza G, Simone S, Villani G, Latorre D, Pontrelli P, Carella M, Paolo F, Grandaliano G, Schena FP : Mitochondrial dysregulation and oxidative stress in patients with chronic kidney disease. BMC genomics $10: 388,2009$

16) Wollensen F, Bratistrom L, Refsum H, Ueland PM, Berglund L, Berns C : Plasma total homocysteine and cysteine in relation to glomerular filtration rate in diabetes mellitus. Kidney Int 55 : 1028-1035, 1999

17) Lowicka E, Beltowski J : Hydrogen sulfide-the third gas of interest for pharmacologist. Pharmacological Reports 59 : 4-24, 2007

18) Taniwaki H, Ishimura $E$, Tabata $T$, Tsujimoto $Y$, Shioi A, Shoji T, Inaba M, Inoue T, Nishizawa Y : Aortic calcification in haemodialysis patients with diabetes mellitus. Nephrol Dial Transplant 20 : 2472-2478, 2005

19) Ishimura E, Okuno S, Taniwaki H, Kizu A, Tsuchida T, Shioi A, Shoji T, Tanata T, Inaba M, Nishizawa Y : Different risk factors for vascular calcification in endstage renal disease between diabetics and nondiabetics : the respective importance of glycemic and phosphate control. Kidney Blood Press Res 31 : 10-15, 2008

20) Beauchamp RO, Bus JS, Popp JA, Boreiko CJ, Andjelkhovich DA : A critical review of the literature on hydrogen sulfide toxicity. Crit Rev Toxicol $13: 25-$ 97, 1984

21) Zhao W, Zang J, Lu Y, Wang R : The vasorelaxant effect of H2S as a novel endogenous gaseous $\mathrm{K}_{\text {ATP }}$ Channel opener. EMBO J 20 : 6008-6016, 2001

22) Wang $\mathrm{R}:$ Is $\mathrm{H}_{2} \mathrm{~S}$ a stinky remedy for atherosclerosis? Atherioscler Thromb Biol 29 : 156-160, 2009

23) Pryor WA, Houk KN, Foote CS, Fukuto JM, Ignarro LJ, Squadrito GL, Davies KJ : Free redical biology and medicine. It's a gas, Man. Am J Physiol Regul Integr Comp Physiol 291 : R491-511, 2006

24) Thuraisingham RC, Yaqoob MM : Oxidative consumption of nitric oxide : a potent mediator of uremic vascular disease. Kidney Int 84 (Suppl) : S29-32, 2003

25) Kruszyna H, Kruszyna R, Smith RP : Cyanide and 
sulfide interact with nitrogenous compounds to influence the relaxiation of various smooth muscles. Proc Soc Exp Biol Med 179 : 44-49, 1985

26) Sohn H, Kuriyama $H$ : The role of amino acids in the regulation of hydrogen sulfide production during ultradian espiratory oscillation of Saccharomyces cerevisiae. Arch Microbiol 176 : 69-78, 2001

27) Yu MF, Gorenne I, Su X, Moreland RS, Kotlikoff MI : Sodium hydrosulfite contraction of smooth muscle are calcium and myosin phosphorylation independent. Am J Physiol 275 : L976-982, 1998 